\title{
ILCEA
}

Revue de l'Institut des langues et cultures

d'Europe, Amérique, Afrique, Asie et Australie

$31 \mid 2018$

Récits fictionnels et non fictionnels liés à des

communautés professionnelles et à des groupes spécialisés

\section{Nanotechnology and the Gray Goo Scenario: Narratives of Doom?}

Les nanotechnologies aux prises avec le scénario de la glue grise: des récits de malheur?

\section{Marie-Hélène Fries}

\section{OpenEdition}

\section{Journals}

Electronic version

URL: http://journals.openedition.org/ilcea/4687

DOI: $10.4000 /$ ilcea.4687

ISSN: 2101-0609

\section{Publisher}

UGA Éditions/Université Grenoble Alpes

\section{Printed version}

ISBN: 978-2-37747-043-3

ISSN: 1639-6073

Electronic reference

Marie-Hélène Fries, « Nanotechnology and the Gray Goo Scenario: Narratives of Doom? », ILCEA

[Online], 31 | 2018, Online since 06 March 2018, connection on 30 April 2019. URL : http://

journals.openedition.org/ilcea/4687 ; DOI : 10.4000/ilcea.4687

This text was automatically generated on 30 April 2019.

(C) ILCEA 


\title{
Nanotechnology and the Gray Goo Scenario: Narratives of Doom?
}

\author{
Les nanotechnologies aux prises avec le scénario de la glue grise: des récits de \\ malheur?
}

Marie-Hélène Fries

\section{Introduction}

1 Researchers in science and technology often oppose science-fiction and science facts, implying that science-fiction is only a figment of the novelist's imagination and certainly not part of "real science". However, the inclusion of the word "science" in science-fiction suggests otherwise (Thévenon, this volume). There seems to be widespread agreement that science-fiction novels, in particular, can shed light on the future societal consequences of present scientific or technological choices, for example the rise of internet, linked to the power of big corporations (cyberpunk fiction) or the impact of human activities on finite environmental resources (the new wave). The aim of this article is to address the question of whether science-fiction novels can be considered part of scientific discourse, in the same way as popularized science and even research articles, and whether the scenario concept, which is routinely used by big companies to adapt their management policies to a range of future plausible situations, can shed light on the scientific and political stakes linked to this question. To begin with, we set out to answer these questions through the example of "gray goo" narratives in nanotechnology. We first define nanotechnology as a specialized domain, scenarios as business tools and gray goo as an embodied metaphor. We then go on to analyze three stages in gray goo narratives: a mere intimation in Drexler's Engines of Creation (1986), a local outburst in Crichton's Prey (2002) and the end of the world as we know it in Bear's Blood Music (1985). Finally, we explore the functions of gray goo from environmental, political, and symbolic points of view. 


\section{Terminology issues}

2 In order to understand what is at stake behind gray goo narratives, as well as their relationship with specialized discourse, we first need to define the gray goo concept, both in reference to nanotechnology and from the point of view of its economic and environmental impact, i.e. as a scenario for the future.

\subsection{Nanotechnology: definition, main applications, stakeholders}

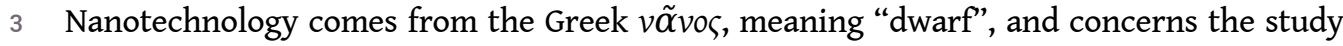
and application of the infinitely small. It is defined by the National Nanotechnology Initiative (NNI), a federal agency in charge of coordinating research and development (R\&D) in this field, as

the understanding and control of matter at dimensions between approximately 1 and 100 nanometers, where unique phenomena enable novel applications. Encompassing nanoscale science, engineering, and technology, nanotechnology involves imaging, measuring, modelling, and manipulating matter at this length scale (NNI, 2010: 1).

4 This definition is based on a specific range of values (1 to 100 billionth of meters, the size of atoms and molecules), highlighting the specificity of the nanoscale, where the influence of the laws of physics fades and quantum effects are felt more strongly. Colors may change, as well as material properties. Nanogold, for example, becomes red. Carbon nanotubes, made of the same carbon atoms as graphite-the material used in pencils-are six times as strong as steel and can conduct electricity.

The study of nanotechnology is not based on particular objects or methods, but on size only (the scale from 1 to 100 nanometers), and so encompasses most scientific and technical fields at that scale, ranging from physics to chemistry, engineering, computer science, and biotechnology. Its applications, therefore, range across many fields, including miniaturized computer chips, new materials (such as carbon nanotubes), or nanovectors able to carry therapeutic molecules to the cells they are targeting in medicine (NNI, 2013).

6 Although the term "nanotechnology" was coined in Japan ${ }^{1}$ in 1974, the United States has played an instrumental role in the development of this new domain since the beginning. According to most historians of science, the birthplace of nanotechnology was in 1959 at Caltech, with Feynman's famous speech entitled "There's plenty of space at the bottom". In this talk, he envisioned miniaturizing motors, computers, and even factories, down to the molecular scale, or, conversely, manipulating atoms one by one. Almost thirty years later, the term "nanotechnology" was popularized by Drexler in his essay Engines of Creation, the Coming Era of Nanotechnology (1986). Then, at the dawn of the new millennium, President Clinton made nanotechnology a priority in federal research policy by launching the NNI, a body in charge of coordinating all the research funded by federal agencies on nanotechnology and promoting R\&D in this domain. ${ }^{2}$

7 Because of its wide range of applications, nanotechnology involves a multiplicity of stakeholders in the United States. Most universities and federal laboratories have research teams working at the nanoscale, mainly in the perspective of technological innovation. Academic communities have numerous links with industries, hospitals, and 
businesses, with the aim to mass produce and commercialize the innovative products they are inventing. They are often in touch with law firms to develop patents and deal with unfair competition. The general public is also involved in nanotechnology issues: tax-payers and electors have their word to say in the funding of research projects and the purchase of the end-products, as nanoparticles and materials are now contained in a fair number of everyday goods, from food to car tires or babies' bottles. ${ }^{3}$ They may also have legitimate questions about health and environment safety issues. Nanotechnology can therefore also be understood in the framework of Latourian networks defined as blends between nature and culture, linking science and society together (Latour, 1991).

Nanosilver, and the debates its uses have sparked in the US, is a clear illustration of the way this nanotechnology network works. Nanosilver is a biocide, regularly used as a disinfectant in dressings or antibacterial surfaces, but also sometimes found in clothes and even babies' bottles. The companies affiliated to the Silver Institute see no need for recognizing nanosilver as a special substance. According to them, it causes the same environmental problems as the slightly bigger colloidal silver particles ${ }^{4}$ which are harmful for living organisms when they are released in the environment. However, the International Center for Technology Assessment (ICTA) does not see things in the same way and in 2007, they asked the Environment Protection Agency (EPA) to classify nanosilver as a pesticide on legal grounds: the patents filed for nanosilver are proof that they have specific properties which may be harmful for the environment (Laurent, 2010: 95-100).

9 The example of nanosilver clearly shows that the development of nanotechnology has societal consequences which cannot be overlooked. Nanotoxicity is the most immediate issue, but medium and long term stakes also involve threats to individual freedom, the enhancement of humankind through nanoprostheses and the brain-computer interface, or even the replacement of human beings by (nano)robots. Forecasting the future of nanotechnology is a difficult task for several reasons: first, existing nanotoxicity surveys sometimes yield conflicting results, and common procedures for assessing the toxicity of nanoparticles and materials are still in the process of being developed, so the precautionary principle is difficult to apply in this context. Secondly, the development of nanotechnology in electronics and computer science is leading to the emergence of what the mathematician John Von Neumann named "complex systems", i.e. systems which cannot be simplified. One of the main characteristics of such systems is that their evolution cannot be predicted before they are implemented (Dupuy, 2007). Finally, the consequences of nanotechnology on human societies depend on people's responses as much as on science and engineering. The risk of nanodevices spying on our private lives is linked to the question of whom the data thus gathered belong to and who has access to them. It is therefore a political and legal problem as much as a technical one. In these conditions, scenarios seem one of the most efficient ways of dealing with the threats linked to nanotechnology and imagining the future in order to prevent the worst (idem).

\subsection{Scenarios}

The term scenario, originally a written summary of events and characters in a film, is also used to depict a predictable sequence of events in the future. They are routinely used in economics and finance. Companies and businesses use scenarios to understand uncertainties, identify factors of risk and develop a range of strategies dealing with 
different situations. Scenarios have also been used in the field of nanotechnology. In 2006, for example, the Centre for Responsible Nanotechnology published NanoTomorrows, a series of "professional-quality scenarios of a near-future world in which exponential general-purpose molecular manufacturing becomes a reality" (CRNano, 2006).

11 The usefulness of scenarios, however, should not hide the theoretical and practical limits of this risk-management tool. Because they are based on what Dupuy (2007) calls "occurring time" (there is only one past and present, but a multiplicity of plausible futures), scenarios cater mostly for the plausible trends of the future. As such, they cannot adequately deal with "black swans" (Taleb, 2007), i.e. highly improbable events which cannot be predicted and yet have a very high impact, for instance 9/11 or Fukushima. Science fiction novels can act as a useful alternative to scenarios in the perspective of black swans, because they are based on "projected time" rather than on "occurring time" (Dupuy, 2007). From that point of view, the future (the science fiction universe) is conditioned by the present (the work of fiction). However, writers have a message to convey and hope that their readers will react to their visions of the future, triggering societal changes (for the present in which they live). The examples of gray goo analyzed in this article will be loosely called "scenarios", first because it is the usual way of referring to gray goo in the context of nanotechnology, and then on account of the diversity of the situations described: they range from local outbursts of out-of-control nanoparticles to global "ecophagy", a term coined by nanoscientist Robert Freitas (2000), to describe situations when whole ecosystems are consumed by nanorobots gone awry.

\subsection{Gray goo}

The gray goo nightmare is a typical example of a black swan. Initially, an informal word meaning a wet, sticky and unpleasant substance, it refers to a dystopian narrative in which nanorobots escape from their laboratories and start reproducing in an uncontrollable manner. When compared to its Latin synonym "ecophagy", which describes a state of the world, it clearly stands out as an embodied metaphor, a bodily expression of disgust. Because gray goo refers to unknown substances entering human bodies and destroying them, it can also be interpreted as a figure of abjectness, the mirror image of bodily fluids being disposed of in daily life (Kristeva, 1983; Milburn, 2008: 119-122).

The grounding of the gray goo scare in bodily experience, perceived through our five senses, allows science fiction writers to portray feelings ranging from surprise to amazement and bewilderment, from apprehension to fear and horror, as we will see below. This strategy of persuasion through the depiction of affects, which has been the hallmark of pathos since classical rhetoric, can be applied to a wide range of situations. In this respect, science fiction fans have developed a rainbow typology of "goo" in which colors match corresponding functions for nanorobots. Blue goo alludes to "police" nanorobots, able to fight and defeat gray goo (that is, if they do not turn into rogue elements...). Green goo refers to the ability to use DNA as a computer code and merge nanotechnology with life sciences, thus leading to the possibility of hybrid genetically modified organisms (GMOs) reproducing in an unpredictable way. Khaki or red goo point to nanoweapons built to destroy everything in the enemy's territory (Phoenix, 2002). These color variations on the gray goo theme have, of course, proved to be a source of 
inspiration for nanotechnology theorists and fiction writers, as we will see in the second part of this article.

\section{Gray goo narratives as scenarios}

Gray goo is a concept inspired by science fiction, such as, for instance Bear's Blood Music (1985), later popularized by Drexler in Engines of Creation (1986: 172-173) as a dystopic narrative exemplifying the dangers of nanotechnology research. Subsequently, the launching of the NNI prompted ethical concerns, voiced in fiction by Crichton's bestselling book Prey (2002). These three works of fiction have been essentially chosen on grounds of their popularity and the related supposition that they thus echo certain public preoccupations: Blood Music received both Nebula (1983) and Hugo (1984) awards for best novelette, before being expanded into a science fiction book. Engines of Creation was translated into Chinese, French, Italian, Japanese, Spanish and Russian. Prey remained 15 weeks on the best-selling list of the New York Times in the autumn 2002, when it was first published (Ball, 2003).

\subsection{Projections for the future: Drexler's Engines of Creation}

15 In Drexler's view, the plausibility of the gray goo scenario is based on an encounter between bottom-up manufacturing and human error. Whereas traditional top-down manufacturing uses bulk material to produce objects, bottom-up manufacturing, on the contrary, puts objects together, atom by atom, through the use of molecular assemblers. In order to work fast enough, these nanorobots must be able to replicate themselves, which induces exponential growth:

Imagine such a replicator floating in a bottle of chemicals, making copies of itself [...].The first replicator assembles a copy in one thousand seconds, the two replicators assemble two more in the next one thousand seconds, the four build another four and the eight build another eight. At the end of ten hours, there are [... ] over 68 billion. In [...] less than two days, they would outweigh the Earth; in another four hours, they would exceed the mass of the Sun and all the other planets combined-if the bottle of chemicals hadn't run dry long before (Drexler, 1986: 59).

If the assemblers are accidentally or purposely designed to feed on common carbon atoms, they can potentially destroy all organic material, including all living organisms:

"Plants" with "leaves" no more efficient than today's solar cells could out-compete real plants, crowding the biosphere with an inedible foliage. Tough, omnivorous "bacteria" could out-compete real bacteria: they could spread like blowing pollen, replicate swiftly, and reduce the biosphere to dust in a matter of days. [...] Among the cognoscenti of nanotechnology, this threat has become known as the gray goo problem (idem: 172).

At the time he wrote Engines of Creation, Drexler therefore considered the gray goo theme as a hypothetical "black swan" that nevertheless needed to be taken seriously because the risks involved were so high: "The gray goo threat makes one thing perfectly clear: we cannot afford certain kinds of accidents with replicating assemblers." (idem: 173)

This narrative (which takes up only two pages of the book) was therefore mostly used as an example of the possible dangers of nanotechnology. It clearly shows Drexler's plea in favor of assessing the benefits but also the hazards of molecular assembly and is followed by various suggestions of action plans for prevention purposes (setting up "shields", 
using building material that cannot easily be found in nature, etc.). From this ethical viewpoint, gray goo is an argument rather than a story, a compelling reason for exercising foresight rather than a narrative. However, Drexler himself was aware that molecular assembly (and gray goo as its dark shadow) could also be used as a source of inspiration for fiction, as he acknowledges in his blog:

Soon after the 1986 publication of Engines of Creation, Stanley Schmidt-the influential editor of Analog Science Fiction and Fact Magazine-advised his stable of writers to read the book and write about the ideas, which at the time constituted the working definition of "nanotechnology". Quickly, then, advanced nanotechnology came to be seen through the lens of fiction (2009: 3).

\subsection{Wake-up call: Crichton's Prey}

One of the most popular novels portraying the world of nanotechnology is Prey (2002). In his preface, Crichton, as a well-known novelist interested in the medical and high tech fields, defines his purpose as the development of a fictitious scenario. He first reminds his readers that evolution in nature is synonymous with constant interactions we cannot fully understand, let alone master:

If we could comprehend the real meaning of evolution, then we would envision a world in which every living plant, insect and animal species is changing at every instant [...] This restless and perpetual change [...] implies a world in which all human actions necessarily have uncertain effects (Crichton, 2002, ix-x).

Crichton then goes on to warn us that the nano-bio-info-cogno (NBIC) convergence will lead to the development of self-replicating artificial entities:

Sometime in the twenty-first century, our self-deluded recklessness will collide with our growing technological power. One area where this will occur is the meeting-point of nanotechnology, biotechnology and computer technology. What all three have in common is the ability to release self-replicating entities into the environment (idem: $\mathrm{xi})$.

Finally, he clearly refers to the encounter between these self-replicators and the natural environment as the main thread of his scenario:

We may hope that by the time [artificial organisms] emerge, we will have settled upon international controls for self-reproducing technologies. [...] But of course it is always possible that we will not establish controls. Or that someone will manage to create artificial, self-reproducing organisms far sooner than anyone expected. If so, it is difficult to anticipate what the consequences might be. That is the subject of the present novel (idem: $\mathrm{xv}$ ). Californian home of a couple with three children, in which the novel starts and ends (exemplifying the possible implications of self-replicator mismanagement on society at large); Silicon Valley offices (which symbolize corporate drive for profits at the expense of safety); and, finally, an R\&D laboratory in the Nevada desert where swarms (nanoparticles acting together to solve problems, thanks to distributed intelligence) of self-replicating nanorobots are being produced. These three spaces are blended together through the narrator-hero, Jack Forman, an unemployed Silicon Valley computer scientist turned into a stay-at-home father and husband, who is suddenly called to the Nevada laboratory for a job as a consultant.

The plot focuses on the R\&D facility in the middle of the desert where most of the action takes place, and which is designed according to a convergence between molecular 
assembly, biotechnology and computer science. The interdisciplinary nature of the Nevada laboratory is made clear through the layout of technical equipment it contains: what the narrator first sees as an octopus is in fact "a massively parallel assembly-line" (Crichton, 2002: 181) using bacteria to produce precursor molecules before self-assembly into nanorobots endowed with AI. Accordingly, the resident research team comprises not only computer scientists and engineers, but also a field biologist, and even a child psychologist.

The development of the scenario is mostly guided by Crichton's technical knowledge, translated in the paratext as a five page bibliography. In the first part of the novel, the plot is based on a genetic algorithm ${ }^{5}$ mimicking the behavior of predators with their prey. In a case of dramatic irony, the narrator-hero has to fight swarms of nanorobots he himself has contributed to producing since he is the creator of the PRED-PREY algorithm they are modelled on. In the second part of the scenario, once the wild swarms have been eradicated, Crichton draws his inspiration from cholera, a disease able to adapt into milder, non-lethal forms (Ewald, 1994; Crichton, 2002: 449-450), to invent a more benign type of nanoswarms which invade human bodies and co-evolve with them symbiotically.

In Prey, the spread of the self-replicating nanoparticles is stopped by the narrator-hero, Jack Forman, helped by the field biologist. Together they manage to blast all the wild swarms with thermite and develop a virus able to kill the bacteria building the nanorobots. The narrator's victory over gray goo is clear right from the beginning, since the first and last pages of the book are devoted to the same night. Consequently, the whole novel is built on a flashback effect, an internal analepsis-the interruption of a chronological sequence of events by narration of earlier events-allowing the hero to recall the main events of his last week: "Sitting here in the dark, it's hard to believe that a week ago my biggest problem was finding a job. It seems almost laughable now" (idem: 2). The initial spread and final defeat of gray goo are also greatly enhanced by locating the R\&D lab in a desert, an environment where things can take place without any outside witnesses.

Prey is therefore a novel in which suspense is skillfully interwoven with didactic segments on nanotechnological developments and the narrator's comments on corporate recklessness to voice Crichton's ethical concerns about techno hazards. Because the narrative remains within the bounds of a realistic fiction and makes no mention of gray goo by name, the plot is restricted to the containment and defeat of nanotech hazards. In order to go beyond these limits towards a full-scale scenario of ecophagy, we need to move towards science fiction.

\subsection{Science fiction novels: Bear's Blood Music}

Bear's Blood Music (1985), is the earliest published record of a whole-scale development of gray goo in fiction. The "notes and acknowledgment" page following the novel clearly presents it as a plausible "black swan". Bear begins by thanking a handful of real life researchers for their help, thus anchoring his fiction in "real" science: "My sincere appreciation to Andrew Edward Dyson, PhD., John Graves, PhD., Dr Richard Dutton, Monte Wetzel, and Dr Percy Russell for access to their laboratories and their valuable time and help" (idem: 288). He then proceeds to mix fact and fiction in his main character, Virgil Ulam (a genetic engineer who injects lymphocytes turned into biocomputers into his own blood, thus triggering a gray goo catastrophe) to jump into "real life": "While 
dropping by a San Diego convention on Hybridoma and Scale-Up research, I spotted Vergil I. Ulam's red Volvo sports car in the hotel parking lot. At the moment, he's a young graduate student looking for part-time employment." (ibid.) Readers are thus invited to interpret the whole novel as the narration of a plausible future of the world, in other words, a scenario. This a posteriori interpretation has been carefully prepared, from the prologue to the epilogue, by infusing the overall structure of the plot with scientific analogies and metaphors.

In Blood Music, the plot is structured by a far-fetched analogy with the cell division process in biology due to different parts of the book being given the names of the various stages of mitosis, a process where a single cell divides into two identical cells (Fries, 2011). The prologue of the novel (idem.: 5), which draws the reader's attention to "little live things-microbes, bacteria, the peasants of nature" is called "interphase", alluding to the length of time elapsing between two successive cell divisions. First comes the prophase (during which the cell membrane disappears and chromosomes start forming), which is mirrored in the novel by the spread of the genetically modified cells inside Ulam's body ( idem: 6-60). The next stage, the metaphase, refers to the time when all the chromosomes line up in the equatorial plane of the cell, separating into similar halves. It corresponds to the onset of the gray goo scare in the novel, when the cells turn into nanocomputers and escape from bodily confinement to invade the whole of North America within a few days, destroying all living organisms on the way. (idem: 61-128). Then comes the anaphase, during which two equal groups of chromosomes separate and move toward the opposite poles of the cell. This is echoed in the novel through the transformation of the American continent by an entirely new civilization, in which the "noocytes' (or cells of the mind) enter ever more deeply into their molecular constituents and finally delve into quantum mechanics (idem: 129-268). Finally, during the final telophase stage, when two complete cells separate from each other, the noocytes spread to the whole of planet Earth and even break free from the laws of physics (idem: 269-287). They then embark on a star trek voyage within their Thought Universe, or "Noosphere", leaving behind them an empty planet Earth and reshaping the universe on their way:

The Earth, for the space of a long, trembling sigh, held together in the maelstrom. When its time came, the cities, towns and villages-the homes and huts and tentswere as empty as shed cocoons. The Noosphere shook loose its wings. When the wings touched, the stars themselves danced, celebrated, became burning flakes of snow (idem: 284).

This unlikely analogy between mitosis and the formation of the Noosphere, which guides the development of the plot, seems far removed from the current state-of-the-art in science and technology. In Blood Music, however, its plausibility is strengthened by the use of theory-constitutive metaphors (Boyd, 1993; Resche, 2012), in particular DNA as a computer or linguistic code (Temmerman, 2000; Nehrlich \& Dingwall, 2003; Fries, 2016). The genetically modified lymphocytes have initially been endowed with computer-like capabilities. This appears as plausible because genes are only part of the DNA, so that the remaining sequences (sometimes called "junk DNA") could be altered by Ulam and used as a computer code, without bringing any changes to the genetic material of the cells. The lymphocytes were thus endowed with AI so that "they would continue learning, adding new segments to the revised portions of their DNA" (Bear, 1985: 17). This provides an essential clue to the plausibility of gray goo, because it explains how information stored in lymphocytes could spread to other kinds of human cells, all prokaryotic cells, and even simple eukaryotic cells such as bacteria. In Blood Music, however, DNA is mostly 
considered as a linguistic code. This metaphor, which can be inferred from standard biological terms such as DNA TRANSCRIPTION into RNA, or RNA TRANSLATION into PROTEINS, also allows Bear to imagine that noocytes are able to communicate with human beings in simple, but very comprehensible English, generally to gather more information on the human world. The noocytes are also willing, occasionally, to answer human beings' questions about the way they are organized and function, which gives the readers an insider's view of the Noosphere.

Blood Music ultimately gives a full scale account of gray goo, leading to the creation of a brand-new Universe. It is also a good example of cyberpunk science fiction, which is situated in the present or the near future, and where the novum (the extraordinary invention which makes the science fiction world possible) is inspired by the current stateof-the-art in science and technology, including theory-constitutive metaphors. This skillful blend between realism and imagination infuses the novel with the flavor of a parable.

\section{Functions of the gray goo threat}

On the whole, gray goo, whether only sketched in speculative writing on science and technology, or more developed in fiction, appears as a scare scenario used to voice ethical questions about the thoughtless development of emerging technologies. These concerns can be divided into three main areas: health and environmental issues, economic and political stakes, and gender-related questions.

\subsection{Environmental wake-up call: use of the gray goo scare by environmentalists}

Only a few months after the publication of Prey, a report entitled From Genomes to Atoms: The Big Down; Atomtech: Technologies Converging at the Nanoscale was released by ETC (Action group on Erosion, Technology and Concentration), a Canadian watchdog organization. Following Drexler's scenario and Crichton's lead, this report presents gray goo as a major environmental hazard:

What if nanobots start building chairs and don't stop? The self-replicating and assembly processes could go haywire until the world is annihilated by nanobots or their products. Gray goo refers to the obliteration of life that could result from the accidental and uncontrollable spread of self-replicating assemblers (ETC, 2003: 30).

In order to bring this point home, ETC uses the three types of argument outlined in classical rhetoric: ethos, logos, and pathos. The appeal to pathos and emotions can be seen in the fact that they use both colors and cultural references in their typology of "goo" (ETC, 2003: 35). Gray goo is aptly named a "sorcerer's apprentice" scenario, in reference to Goethe's ballad, which later inspired Dukas's music (1894) and the Disney film Fantasia (1940 \& 2000) in which a young lad uses one of his absent master's spells to bring a broom to life and orders it to fill a cauldron with water for him, but then finds himself unable to stop the broom... "Blue goo" (the color of police uniforms), alludes to the rising power of AI to the point that they could control the Earth: "super machines evolve to manage complex human and environmental systems and (eventually) either take over the world or fall into the hands of an omnipotent corporate elite" (ibid.). This is named the "Brave New World" scenario in reference to Aldous Huxley's novel (1932), depicting a caste 
society in which most of humanity has become enslaved to a ruling elite. Finally, "green goo" refers to the Earth's invasion by genetically-engineered bacteria conceived as nanomachines: "Scientists combine biological organisms and mechanical machines for industrial uses [...] the emboldened bacteriophage becomes the omniphage." (ibid.) This last scenario is called "Toys'r us", the name of well-known chain of toy stores, thus implying that scientists are "playing" at the nanoscale and will no more be able to control the possible consequences of their "games" on the environment than the sorcerer's apprentice.

However, a quick look at the contents of the The Big Down report shows that the three-goo theory could easily be interpreted as part of logos as well as pathos. It comes as the end point of a four step process: first, nanoparticles, followed by the self-assembly of atoms and molecules into supra-molecular forms; then molecular manufacturing (from single atoms to whole objects); and finally, the convergence of biology and material sciences at the nanoscale, leading to the "goo" scenarios (ETC, 2003: 20-37). This logical sequencing makes gray goo look inescapable, all the more so as it is framed in a larger historical perspective, in which, from the Renaissance onwards, technological progress has fostered inequality:

Economists see technological advancement to be the rising tide allowing benefits and abundance to "trickle down" from those first enriched eventually to all. History suggests otherwise. From Europe's Renaissance to America's "IT" revolution, humanity has been marched through a succession of industrial revolutions that-in their early generations-have further dis-empowered and disabled marginal groups (idem: 9).

ETC systematically refer to history in their report in order to give weight to their analysis of the risks linked to nanotechnology in view of past precedents, thus creating a public image of reliability and seriousness. This ethos-forming effort is also apparent through the numerous endnotes. The bibliographical references they contain refer to a broad range of writers, including key nanotechnologists such as Feynman, Drexler, and Smalley. The Big Down ends with references to useful internet sites and a glossary. In the light of this well-documented work, the gray goo threat appears more plausible and serious, thus adding weight to ETC's call for a moratorium:

Given the concerns raised over nanoparticle contamination in living organisms, ETC Group proposes that governments declare an immediate moratorium on commercial production of new nanomaterials and launch a transparent global process for evaluating the socioeconomic, health and environmental implications of the technology (idem: 72).

For Crichton as well as the ETC group, the gray goo scare seems therefore to be an extreme example of a heedless development of molecular assembly. Prey and The Big Down are proof that, thanks to its vivid imagery, blended with a linear conception of scientific "progress", and to the support of pioneer figures such as Drexler, gray goo has been successfully used by environmentally-sensitive stakeholders to attract public attention to the risks and hazards linked to nanotechnology. ${ }^{6}$

\subsection{Scarecrow syndrome: economic and political stakes}

From an economic point of view, nanotechnology holds the promise of innumerable benefits, especially in terms of creating both start-ups and jobs, increasing company 
profits, and maintaining the US technological edge. In a first report on the NNI, the National Research Council stated that:

With potential applications in virtually every existing industry and new applications yet to be discovered, there is no doubt that nanoscale science and technology will emerge as an important driver of economic growth in the first years of the new millennium (NRC, 2002: 23).

The threat of a moratorium, therefore, needed to be taken seriously. Molecular assembly, and the gray goo scare it could lead to, were quickly identified by business and scientific circles alike as the main cause of this threat, and it became urgent to separate current research on nanoparticles and nanosystems from "revolutionary" nanotechnology. Leading nanoscientists vehemently questioned the feasibility of gray goo in an open public debate (Smalley, 2001: 76-77; Whitesides, 2001: 78-83). Lobbies such as the NanoBusiness Alliance succeeded in excluding molecular manufacturing from funding in the 2003 Twenty-First Century Nanotechnology Research and Development Act, ostensibly because "There was no interest in the legitimate scientific community-and ultimately Congress-for playing with Drexler's futuristic sci-fi notions" (Mark Modzelewski of the NanoBusiness Alliance, quoted in Rawstern, 2003). In response to these attacks, Drexler officially denied any usefulness to the gray goo concept in Nanotechnology journal:

\begin{abstract}
Nanotechnology-based fabrication can be thoroughly non-biological and inherently safe: such systems need have no ability to move about, use natural resources, or undergo incremental mutation. Moreover, self-replication is unnecessary: the development and use of highly productive systems of nanomachinery (nanofactories) need not involve the construction of autonomous self-replicating nanomachines (Phoenix \& Drexler, 2004: 869).
\end{abstract}

In spite of this refutation, a "nanotechnology and gray goo" query on the Google search engine shows that a number of academic sites continued to refer to gray goo even after Drexler's dismissal of the concept in 2004 (Fries, 2016: 153-159). Rice University, for instance, has included gray goo in its early history of nanotechnology, explaining both Drexler's scenario and later criticism by Smalley:

Primarily, Drexler warns of the gray goo, an amalgamation of self-replicating nanobots that would consume everything in the universe in order to survive. [...] Some scientists have criticized Drexler's visions as impossible and harmful. Richard Smalley has led this movement against Drexler's almost sensationalist vision of molecular manufacturing. [...] Furthermore, he also chastises Drexler for his gray goo scenario, saying, "you and the people around you have scared our children" (Fanfair, Desai \& Kelty, 2005).

The persistent thrashing of gray goo in academic circles even after Drexler's public change of opinion in 2004 begs the question of why this dead horse should be flogged. From a rhetorical point of view, Milburn suggests that gray goo may have been used as a prototypical process, highlighting and subsuming all the risks linked with nanotechnology, in other words, a metonymy for nanohazards (2008: 114-129). Exposing gray goo as unrealistic fiction allowed nanoscientists to set aside public fears about nanotechnology, and thus proceed with their research undisturbed. A clear sign that Milburn's analysis may well be right is that Drexler himself paid a high price for his popularization of gray goo. He found himself evicted from the "legitimate scientific community" and the more he protested, the more he was ostracized. He eventually had to leave the Foresight Institute he had co-founded and move to Oxford due to the position of scapegoat he found himself in: 
Sacrificing Drexler prevents disintegration of the legitimate scientific community over issues of molecular self-assembly and self-replication; it localizes any larger problem of nanodanger to the fantasies of one man and enables the social field to come together and pretend as if there were no uncertainty as to its ability to ultimately control matter (Milburn, 2008: 125).

It therefore looks as if gray goo itself played the part of a scapegoat in the first years of the NNI, allowing scientific, business and political circles to condensate all the hazards linked to nanotechnology into this scare scenario. Thereafter it was a relatively easy task to expose it as mere fiction, and so down-play all the other risks linked to nanotechnology, thus persuading the public that leaving nanorisk assessment to academic experts was far more preferable. This can explain why environmental watchdog organizations were not the only stakeholders involved in referring to gray goo and how this scare scenario spread from environmental concerns to economic and political issues. It does not account, however for the reason why the gray goo concept caught on so quickly, a question we address by delving into the highly metaphoric nature of gray goo and its symbolic character.

\subsection{Gray goo as the reverse of mastery: gender imbued symbolism}

Drexler's grand design of molecular manufacturing, bringing peace, economic prosperity and, ultimately, immortality, is founded on the ability to manipulate Nature at the atomic and molecular level. In other words, he presents nanotechnologists as master-builders: "Because assemblers will let us place atoms in almost any reasonable arrangement [...], they will let us build almost anything that the laws of Nature allow to exist" (1986: 14). This can be interpreted as a demiurgic posture on the part of nanotechnologists, as Bensaude-Vincent has pointed out: "the artisan, like Plato's demiurgos, builds up a world by imposing his own rules and rationality on a passive matter. Technology is a matter of control." (2004: 78)

In contrast, gray goo appears as a total lack of control, the ultimate failure of mastery. For Milburn (2008), this dichotomy is deeply rooted in gender differences. He sees the ability to move atoms one by one thanks to the tip of a scanning tunneling microscope as linked to a symbolic patriarchal phallus, and "goo" as the wet fertility of a woman's womb. The main characters in Prey embody this perception. The hero-narrator, who finally manages to destroy all the nanoswarms, sums up this mission in terms of his own name: Jack Forman, i.e., literally, for man. His wife Julia, on the other hand, is doubly responsible for the onset of the gray goo threat: as company Vice-President, she was originally responsible for setting the nanoswarms free in the wild. She subsequently tames one of them, ending up in a monstrously symbiotic relationship with nanoparticles in turn colonizing her.

Crichton's patriarchal interpretation of "goo" in Prey looks very different from Bear's postmodernist version. In Blood Music, the noocytes create an entirely new civilization, tinted with what could look like stereotypical feminine values: collaboration supersedes competition, all personal memories are encoded and preserved before bodies collapse into puddles of goo, and a myriad of possible new choices become possible in postbiological life, as one of the characters discovers in a conversation with the noocytes:

- I have lost far too many illusions.

What would you wish to revise There are options.

- I don't understand. 
?

- If you mean go back, I don't see how.

It is all possible here, in the Thought Universe. Simulations. Reconstructions

from your memory.

- I could live out another life?

When there is time.

(Bear, 1985: 242) relationship between scientific discourse and science-fiction. The analysis of gray goo narratives has shown that scenarios bridge the gap between societal issues linked to science and technology, on the one hand, and science-fiction on the other, as they open the door to prospective thinking on emerging science and innovations. In Engines of Creation, gray goo is sketched as a "black swan", a low-probability but high-impact event -e.g. a reactor melt down in a nuclear power station-that calls for preemption measures. In Prey, the gray goo narrative is embodied in human characters and cultures, as well as inspired by specialized content. It exemplifies Crichton's message that emerging technology trends should be more closely monitored in order to prevent possible risks, but evokes no real protection other than human integrity and resourcefulness. In Blood Music, Bear imagines what the full-scale impact of gray goo could be like through the depiction of an entirely new civilization. However, he makes no mention of prevention since one of the main points of his narrative is to show the Noosphere as better than our current world, barely masking a parable for our hic et nunc. These three science fiction novels can therefore, to varying degrees, be considered as scenarios exploring the future development of emerging techniques and their societal consequences, providing evidence that if fictional narratives on emerging technologies are peripheral, they are nevertheless a vital part of scientific discourse since they allow us to explore the societal consequences of possible technological choices,

Moreover, the various links created between specialized discourse and its "beyond" offer insights into the ambiguous relationship between science and science fiction. Nanotechnologists, the same as other researchers in emerging fields, need official recognition both in terms of publications in specialized journals as well as jobs in academic institutions. In order to reach those aims, they have to keep science fiction at 
bay, dismissing both Drexler's molecular assemblers and the gray goo threat as figments of imagination. At the same time, they still need to refer to "revolutionary" molecular nanotechnology to gain funding for their experiments, as stain-free glass and transparent sunscreens are hardly as likely to attract the same attention as the prospect of mastery at the nanoscale. In this respect, gray goo, through the symbolic, environmental, and political roles it plays in society, is not so much a narrative of doom as a catalyzer of ambiguity.

\section{BIBLIOGRAPHY}

BALL Philip (2003), “Nanotechnology in the firing line”, Nanotechweb.org, on line: <https:// www.philipball.co.uk/articles/nanoscience/69-nanotechnology-in-the-firing-line> (March 20, 2017).

BEAR Greg (1985), Blood Music, New York, NY: E-reads.

BENSAUDE-VINCENT Bernadette (2004), “The two Cultures of Nanotechnology”, HYLE, International Journal for Philosophy of Chemistry, 10(2), 65-82, <http://www.hyle.org/journal/issues/10-2/ bensaude.htm>.

BOYD Richard (1993), “Metaphor and theory change: What is 'metaphor' a metaphor for?", A. Ortony (ed.), Metaphor and Thought [1979], Cambridge, UK: Cambridge University Press, 481532 .

CRICHTON Michael (2002), Prey, New York, NY: Harper \& Collins.

CRNANO (2006), NanoTomorrows, on line: <http://www.crnano.org/CTF-Scenarios.htm> (March 25, 2017).

DREXLER Eric (1986), Engines of Creation: The Coming Era of Nanotechnology, New York, NY: Anchor Books.

DREXLER Eric (2009), “Nanotechnology in science-fiction (and vice versa)”, Metamodern, on line: < http://metamodern.com/2009/04/09/nanotechnology-in-science-fiction/> (March 15, 2013).

DUPUY Jean-Pierre (2007), “Complexity and uncertainty: a prudential approach to nanotechnology", F. Allhoff et al. (eds), Nanoethics: the Ethical and Social Implications of Nanotechnology, Hoboken, NJ: Wiley, 119-131.

ETC (2003), From Genomes to Atoms: The Big Down. Atomtech: Technologies Converging at the Nanoscale, on line: <http://www.ratical.org/ratville/AoS/thebigdown.pdf> (March 7, 2017).

EWALD Paul (1994), Evolution of Infectious Disease, New York, NY: Oxford University Press.

FANFAIR Devon, DESAI Salil, \& KELTY Christopher (2005), “The early history of nanotechnology”, OpenStax, <http://docplayer.net/12086088-The-early-history-of-nanotechnology.html> (March 20, 2017).

FEYNMAN Richard (1960), “There's plenty of space at the bottom”, Caltech Engineering and Science, 23(5), 22-36, <http://www.zyvex.com/nanotech/feynman.html>. 
FREITAS Robert (2000), "Some Limits to Global Ecophagy by Biovorous Nanoreplicators, with public Policy Recommendations”, Foresight Institute, <http://www.foresight.org/nano/ Ecophagy.html> (April 16, 2017).

FRIES Marie-Hélène (2011), "De l'utilité des métaphores dans le style scientifique", Études de Stylistique Anglaise, 2, 57-71, <http://stylistique-anglaise.org/wp-content/uploads/ESA-N\%C2\% B0-2.pdf>.

FRIES Marie-Hélène (2016), Nanomonde et Nouveau monde, Grenoble, France: Éditions Littéraires et Linguistiques de l'université de Grenoble.

HUXLEY Aldous (1932), Brave New World,London:-Chatto \&Windus.

KRISTEVA Julia (1983), Pouvoirs de l'horreur. Essai sur l'abjection [1980], Paris, France: Seuil.

LATOUR Bruno (1991), Nous n'avons jamais été modernes, Paris, France: La Découverte.

LAURENT Brice (2010), Les Politiques des nanotechnologies. Pour un traitement démocratique d'une science émergente, Paris, France: Éditions Charles Léopold Mayer.

MILBURN Colin (2008), Nanovision: Engineering the Future, Durham, NC: Duke University Press.

NATIONAL RESEARCH COUNCIL (2002), Small Wonders, Endless Frontiers: A Review of the National Nanotechnology Initiative, Washington, DC: The National Academies Press, <http://www.nap.edu/ catalog/10395.html>.

NEHRLICH Brigitte \& DINGWALL Robert (2003), "Deciphering the human genome: The semantic and ideological foundations of genetic and genomic discourse", R. Dirven et al. (eds), Cognitive Models in Language and Thought, Berlin, Germany: Mouton de Gruyter, 395-428.

NNI (2010), “Nanotechnology 101. What It Is and How It Works”, Nano.gov, on line: <https:// www.nano.gov/nanotech-101/what> (March 25, 2017).

NNI (2013), “Triennial Review of the National Nanotechnology Initiative", Washington, DC: The National Academies Press, on line: <http://www.nap.edu/catalog/18271/triennial-review-of-thenational-nanotechnology-initiative $>$ (March 25, 2017).

NNI (2017), “NNI Budget", Nano.gov, on line: <https://www.nano.gov/about-nni/what/funding> (May 25, 2017).

PHOENIX Christopher \& DREXLER Eric (2004), “Safe exponential manufacturing”, Nanotechnology, 15 (8), 869-872.

PHOENIX Chris (2002), “Goo vs Paste”, Nanotechnology now, on line: <http://www.nanotechnow.com/goo.htm> (March 15, 2017).

RAWSTERN Rocky (2003), “Omission in the $21^{\text {st }}$ Century Nanotechnology Research and Development Act”, Nanotechnology Now, on line: <http://www.nanotech-now.com/ MNT-12092003.htm> (March 25, 2017).

RESCHE Catherine (2012), “Towards a better understanding of metaphorical networks in the language of economics: the importance of theory-constitutive metaphors", H. Herrera-Soler \& M. White (eds), Metaphors and Mills, Berlin, Germany: Mouton de Gruyter, 77-102.

SMALLEY Richard E. (2001), "Of chemistry, love, and nanobots”, Scientific American, September issue, 76-77, <http://cohesion.rice.edu/naturalsciences/smalley/emplibrary/sa285-76.pdf> (April 30, 2017). 
TALEB Nassim N. (2007), The Black Swan or the Impact of the Highly Improbable, New York, NY:

Random House.

TEMMERMAN Rita (2000), Towards New Ways of Terminology Description: The sociocognitive approach, Amsterdam: John Benjamins.

WHITESIDES George (2001), “The art of building small”, Scientific American, September issue, 32-47, < https://gmwgroup.harvard.edu/pubs/pdf/760.pdf> (April 30, 2017).

\section{NOTES}

1. The first documented use of nanotechnology comes from Pr Tanaguchi from Tokyo Science University.

2. The cumulated budget of the NNI has been almost 24 billion dollars since 2000 (NNI, 2017: 2).

3. A regularly updated "Nanotechnology Consumer Products Inventory" is published on the internet site of the Project for Emerging Technology: <http://www.nanotechproject.org/ inventories/consumer/ browse/> (March 30 2017).

4. Colloidal silver ranges from 100 to 1000 nanometers.

5. Genetic algorithms use the principles of Darwinian evolution to solve problems through gradual adaptation.

6. Prince Charles, for example, asked for a scientific report on nanotechnology, after reading Prey (Ball, 2003).

\section{ABSTRACTS}

The aim of this article is to address the question of whether science-fiction novels can be considered part of scientific discourse, in the same way as popularized science or research articles, and whether the scenario concept can shed light on the scientific and political stakes linked to the question. The analysis of three examples of gray goo narratives from the specialized domain of nanotechnology shows that they can be considered as scenarios exploring the future development of emerging techniques and its consequences for society, while at the same time highlighting the ambiguous relationship between science and science fiction in innovative technologies.

Le but de cet article est d'étudier la question de l'appartenance ou non des romans de sciencefiction au discours scientifique, au même titre que la vulgarisation scientifique ou les articles de recherche, et de voir si le concept de scénario peut mettre en lumière les enjeux scientifiques et politiques liés à cette question. L'analyse de trois exemples de récits de " glue grise » relevant du domaine spécialisé des nanotechnologies, montre qu'ils peuvent être considérés comme des scénarios explorant l'évolution future des techniques émergentes, tout en soulignant l'ambiguïté de la relation entre science et science-fiction pour les technologies novatrices. 
INDEX

Keywords: gray goo, metaphors, nanotechnology, scenarios, science-fiction, ESP

Mots-clés: anglais de spécialité, glue grise, métaphores, nanotechnologies, scénarios, sciencefiction

\section{AUTHOR}

MARIE-HÉLÈNE FRIES

Université Grenoble-Alpes (UGA) 